\title{
КОНЦЕПТУАЛИЗАЦИЯ И КАТЕГОРИЗАЦИЯ В ЯЗЫКЕ С ПОЗИЦИИ ЛИНГВОКУЛЬТУРОЛОГИИ
}

\author{
ВАЛЕНТИНА МАСЛОВА \\ Витебский государственный университет им. Петра Машерова \\ Филологический факультет \\ Кафедра кафедры германской филологии \\ Проспект Московский 33, 210038 Витебск, Беларусь \\ e-mail: mvavit@tut.by \\ (получено 21.04.2018; принято 10.09.2018)
}

\begin{abstract}
Conceptualization and categorization in terms of linguoculturology

This paper attempts to show that the concept of interaction between language and culture is a key concept of a whole series of adjacent human sciences. It is the cross-cutting idea that breaks the borderlines between various disciplines investigating human beings. That is why modern linguocultural studies is not only concerned with interrelation of language and culture, but it also attempts to solve the problem of relationship between language and people's consciousness and mentality. Cognitive linguistics drew attention to the problems of categorization and conceptualization of language awareness, which eventually enriched linguocultural studies.
\end{abstract}

\section{Key words}

Conceptualization, categorization, classification, anthropocentricity, integrative features, linguocultural studies. 


\section{Реюме}

В статье показано, что концепция взаимодействия языка и культуры является ключевой для ряда смежных наук о человеке. Это та сквозная идея, которая разрушает границы между дисциплинами, изучающими человека. Поэтому и современная лингвокультурология исследует не только взаимовлияние языка и культуры, но и пытается решить проблему соотношения и взаимосвязи языка и личности, ее сознания, мышления. Когнитивная лингвистика обратила внимание на проблемы категоризация и концептуализация знаний в языке, что в конечном счете обогатило и лингвокультурологию.

\section{Ключевые слова}

Концептуализация, категоризация, классификация, антропоцентричность, интегративность, лингвокультурология.

При антропоцентрическом подходе анализируется человек в языке и язык в человеке, поскольку, по словам Ивана Александровича Бодуэна де Куртэне, «язык существует только в индивидуальных мозгах, только в душах, только в психике индивидов или особей, составляющих данное языковое общество» (Бодуэн де Куртэне, 1963, с. 71). Идея антропоцентричности языка стала ключевой в современной лингвистике. Есть и другие идеи, ставшие принципами современной лингвистики - интегративность, коммуникативность, диалогичность, дискурсивность, культуроцентричность, интерес к глубинным знаниям в языке и др. Данные принципы, как правило, в современных исследованиях взаимодействуют и обусловливают друг друга, например, интегративность позволила более отчетливо увидеть глубинные семантические основы языка и человеческой ментальности, что привело к зарождению когнитивной лингвистики.

Когнитивный подход оказывается сегодня ключом к решению тех вопросов, исследование которых без обращения к анализу познавательных процессов оставались бесплодными, например, все проблемы, касающиеся языкового сознания, понимания и др.

С позиции названных принципов, меняется и лингвокультурология. Еще ранее стало понятно, что в концепции язык и культура сходятся интересы всех наук о человеке, что это та сквозная идея, которая разрушает границы между дисциплинами, изучающими человека. Поэтому и современная лингвокультурология должна исследовать не только взаимодействие языка и культуры, но и решить проблему соотношения и взаимосвязи языка и личности, ее сознания, мышления.

Проблемы языкового сознания и обеспечивающих его мозговых механизмов чрезвычайно важны, потому что мы видим и познаем мир так, как это позволяет наш мозг: мир для нас таков, каким мы способны его воспринять и описать. Язык - особая видоспецифическая способность мозга. Об этом уже пишут сейчас исследователи (Томас Нагель, Татьяна Владимировна Черниговская, Жанна 
Ильинична Резникова и др.). А это - междисциплинарная проблема, решение которой возможно только усилиями нескольких наук - от философии, этнолингвистики, лингвокультурологии до биологии и физиологии.

Под влиянием новых знаний изменилась и когнитивная лингвистика, в которой ранее языковое знание определялось в качестве отдельного модуля ментального пространства человека.

Современные лингвисты отмечают важность категориального формата и считают его ведущим в организации языка (Болдырев, 2009, с. 77), поэтому категория - важнейшее понятие в лингвистике (особенно в морфологии, синтаксисе). Это одно из ключевых понятий и в когнитивной лингвистике.

Задача данной статьи - показать, как категоризация и концептуализация отразилась на развитии лингвокультурологии, и доказать, что существующие категории - это интегративные знания, т.к. любая категория включает знания а) общего концептуального основания объединения объектов, б) самих объединяемых объектов, которые должны иметь общие существенные свойства, в) принципов и механизмов их объединения.

Категоризацию следует отличать от концептуализации, которая есть сердце когнитивистики. Вероятно, их связующим звеном будут семантические категории. Поэтому семантические категории рассматриваются нами в едином концептуальном и культурном пространстве. Но здесь встает вопрос об их дифференциации не только между собой, но и от процессов классификации.

Попытаемся разобраться в данном вопросе. Учение о категории восходит к Аристотелю, определявшему этой лексемой результат процесса классификации явлений действительности. Термин категория широко используется в философии, где означает одну из познавательных форм мышления человека. Здесь категория - общее понятие, отражающее наиболее существенные свойства и отношения предметов, явлений объективного мира (категории материи, времени, пространства, движения, причинности, качества, количества и т.д.). В лингвистике категория - любая группа языковых элементов, выделяемая на основе какого-либо общего свойства; (...) некоторый признак (параметр), который лежит в основе разбиения обширной совокупности однородных языковых единиц на ограниченное число непересекающихся классов (...) (Лингвистический энииклопедический словарь, 1990, с. 215).

Следовательно, в определение лингвистической категории входит понятие класса.

В современной лингвистике термин категория используется как в философском значении (категория времени и ее отражение на разных уровнях языка), так и в чисто лингвистическом (категории членов предложения, категория синтаксической модальности).

Однако с развитием когнитивной лингвистики появилась возможность посмотреть на категории языка сквозь призму опыта: «Мы склонны смотреть на язык как на простую технику выражения, не трудясь объяснить себе, что язык - это прежде всего классификация и упорядочивание потока чувственного опыта, которое ведет к упорядочиванию данного мира» (де Мауро, 2000, с. 163). 
Категоризация - это ключевое понятие в описании познавательной деятельности человека. Специфика языковых категорий обусловлена осмыслением различного человеческого опыта, зафиксированного в языковых формах. В основе опыта лежат следующие типы языковых знаний: 1) знание об объектах окружающего мира, представленное в системе лексических единиц; 2) знание собственно языка как феномена языковых форм, представленное в системе грамматической категоризации, и 3) знание языковых единиц и категорий модусного характера с позиций внутреннего концептуального содержания, которые репрезентируют особенности человеческого сознания.

С точки зрения когнитивной лингвистики, категориальному формату знания и специфике языковых категорий посвящена работа Николая Николаевича Болдырева Концептуальная основа языка (2009), в которой феномен категоризации осмысляется в рамках когнитивно-дискурсивной парадигмы языка.

Итак, категоризация - это включение сущности объективного мира в определенную рубрику, т.е. это способность классифицировать явления и распределять их по рубрикам. Причем, объединяются сейчас в одну рубрику члены с неравным статусом, с не полностью повторяющимися признаками. Людвиг Витгенштейн назвал это «фамильным сходством», при котором обнаруживается чаще всего один общий признак. Если продолжить эту мысль ученого, то один внук похож на деда - ростом, другой характером, третий поведением и т.д. Так и в языке: в одну рубрику «ягоды» объединяются не только вишни, земляника, смородина, но и арбузы.

Вероятно, эта способность к категоризации - врожденная, о чем говорят эксперименты: маленькие дети, не зная наименований, почти безошибочно раскладывали фрукты и овощи по разным кучкам. На этой идее Анной Вежбицкой и Джорджем Лакоффом была создана протитипическая семантика.

Естественный язык является одним «из семиотически наиболее универсальных способов концептуализации», по Веронике Николаевне Телия (2005, с. 9). Отсюда все возрастающее стремление лингвистов к выделению абстрактных глобальных явлений: концепция местоимений как «смысловых исходов» Натальи Юльевны Шведовой, «категоризации семантики» в системе функциональной грамматики Александра Владимировича Бондарко, «сеть прецедентных текстов» Юрия Николаевича Караулова, объединенных им в отдельную парадигму. Это и есть тенденция к высокой степени абстракции знаний через «категоризацию мира», благодаря которой мы получаем способ экономного отражения мира в языке.

Таким образом, новая теория категоризации, по мнению лингвистов, является одним из основных достижений когнитивной лингвистики на сегодняшний день. Тип категоризации, с точки зрения Дж. Лакоффа, определяется несколькими когнитивными моделями: пропозициональной, образом-схемой, метафоричной и метонимичной.

Посмотрим только на одну - метафорическую модель. Покажем это на примере культурной метафоры. Культурная метафора - это призма, сквозь которую видит мир носитель конкретного языка. Данный термин ввел американский психолог Мартин Гэннон в середине 2000-х годов. Сейчас активно исследуется 
когнитивная метафора, но не менее важна и культурная. Метафора вообще это инструмент познания окружающего мира, это универсалия сознания, культуры и языка. Метафорическое видение мира современные психологи склонны связывать с генезисом человека. Некоторые лингвисты даже утверждают, что весь наш язык - это кладбище метафор.

Культурная метафора - это то, что знают все носители данной лингвокультуры и используют в коммуникации: не отходя от кассы, задирать нос, дядя Сэм, русский медведь, шиш в кармане и др.

Метафоры опираются на наш практический опыт. Рассмотрим здесь универсальные пространственные метафоры, т.к. чувство пространства чрезвычайно важно для человека вообще. Но даже они имеют культурный аспект. В основе ориентационных метафор лежат оппозиции верх - низ, внутри - снаружи, впереди - сзади, глубокий - мелкий, высокий - низкий, иентральньй - периферийныци, слева - справа, небо - земля и др. В каждой культуре ориентационная метафора разрастается в целые «деревья», становясь многоликой. Так, метафора пути стала одной из самых востребованных в русской культуре в ситуации смены пути - перепутья. С ней тесно связана метафора транспорта, идущего по этому пути: государственная машина, локомотив истории.

Путь (пространственная метафора) - это следование к достижению цели: жизненный путь, творческий путь, путь к Богу, истине; путь связан с целым рядом позитивных явлений: путное дело, напутствие, но в культуре он представлен и негативными смыслами - nуmь на Голгофу, последний nyms, бесnymье, беспутный, непутевый, перепутье, распутииа. Блуждание без пути - блуд. И язык хранит этот смысл: распутник. Распутица - путь Дьявола в народном сознании. Напутствие - это благословение в дорогу. Символическое значение пути в религиозном контексте - это еще и временная земная жизнь.

Путь имеет моральные, этические, идейные, конфессиональные коннотации: путь к коммунизму, жизненный путь, вступить на новый путь, исторический путь страны. Путеводная звезда в Евангелии. Молитва к Богу: направь меня на nуть истинный... Путеводительство занимает важное место в русской картине мира, отсюда поводьрь, проводник. В западноевропейских языках более активна метафора дороги.

Русский nymь горизонтален: в рай можно дойти; западный путь - вертикален, отсюда готика. Борис Пастернак в Докторе Живаго дает следующее понимание пути: пространственные перемещения ведут к преображению героя. Отсюда чисто русская установка - не сужать, а расширять «свое» пространство: не свет клином сошелся, найдешь свой путь.

Даже если метафоризируются похожие единицы сопоставляемых языков, полной идентичности не бывает, т.к. в этом случае национальная специфика проявляется в количестве производных значений и/или в направлении метафоризации. Например, русская лексема лист и немецкая das Blatt имеют сходное метафорическое значение в обоих языках, однако употребление этой лексемы для называния лопатки в анатомии животных есть только в немецком.

Итак, метафора - это форма организации человеческого опыта, метафоры не столько украшают нашу речь (тексты), как формируют новые мыслительные 
схемы и категории, являются своего рода «мотором» познания, типом образа мира. Владимир Григорьевич Гак утверждал, что метафоры появились в нашей речи не потому, что с ними красивее, а потому, что без них нельзя (Гак, 1988, c. 481).

Тесно связано с категоризаций явление концептуализации мира. Фактически, оба этих процесса - это классификационная деятельность человека, но с разными результатами и целями: концептуализация направлена на выделение минимальных единиц человеческого опыта, категоризация имеет целью объединение единиц, проявляющих хотя бы частичное сходство, в более крупные разряды (Лингвистический энииклопедический словарь, 1990, с. 215). Поэтому концепт - минимальная единица знания. Именно концептуализацию большинство когнитологов считают ключевым понятием когнитивной лингвистики (Дж. Лакофф, Елена Самуиловна Кубрякова, Н. Н. Болдырев и др.).

Ключевым оно является и для лингвокультурологии (Владимир Ильич Карасик, Мария Львовна Ковшова, Виктория Владимировна Красных, Валентина Авраамовна Маслова и др.), в ней активно развивается понятие концептосферь культурь, которая понимается как «сложнейшее системное образование, которое создается из концептуально оформленной ценностной информации...» (Словарь тингвокультурологических терминов, 2017, с. 48).

По совокупности ключевых концептов и отношениям между ними можно определять тип культуры. Например, европейская культура - это культура дерева, арабская - цивилизация камня. Камни для арабов обладают сакральной силой, они объект поклонения, камни присутствуют в обрядах погребения, поминовения, наказания (побивание камнями).

Мировое дерево у разных народов различно: для финна, вероятно, это сосна, для немца - дуб, который был главным священным деревом еще у древних германцев, для русского - береза. Славяне жили в основном в лесах и потому относились к деревьям с особым почтением: до сих пор береза, дуб, ель, яблоня, груша, вишня у славян - это символы доброго начала; калина, рябина, осина - символы несчастья. В основе этих представлений лежит архетип дерева - тотема.

Таким образом, концепт дерева может выступать в качестве универсальной концептуальной модели, позволяющей организовать и структурировать окружающее человека пространство. А если посмотреть на проблему шире, то сам человек - микрокосм, объединяющий в себе все элементы вселенной. Человек и Космос едины и повторяют друг друга: голова - это небо, глаза - солнце, волосы - деревья и т.д.

Мировидение у разных народов различно: одни и те же концепты по-разному осмысляют сущность и мир в целом. Например, вера для русских и белорусов - это поиски истины, смысла жизни, богопочитание. В европейском языковом сознании - вера = религии (от лат. «связывание»), т.е. это узы, связывающие нас с Богом.

Если взять на рассмотрение базовые национальные концепты, то конфигурация и удельный вес их в каждой культуре различен, они по-разному связаны между собой. Так, базовыми для русской культуры в начале двухтысячных го- 
дов были - быт, воля, дружба, душа, сердие, закон, здоровье, свобода, тоска, язык (Карасик, Стернин, 2005, с. 21); в 2010 - жизнь, смерть, небо, горе, радость, знание, ум, лень, обман, молитва (Бабенко, 2010, с. 34). Для белорусов же - родина, народ, язык, воля, семья, доля (лес), любовь (каханне), счастье (Пивовар, 2015, c. 54).

Как известно, различия между двумя любыми культурами практически бесчисленны, в связи с чем неизбежно возникает вопрос: какие именно оязыковленные фрагменты культуры нужно сравнивать, чтобы выявить специфику данной культуры? Как язык отражает и задает параметры культуры? Однозначных ответов на данные вопросы пока нет. Широкое распространение получила типология, авторами которой являются Флоренс Клакхон и Фред Стродбек (Лурье, 1997, с. 72-81). Они выделили пять ценностных измерений, выражающих отношение представителей той или иной культуры к ключевым ценностям. Предложенная этими авторами классификация такова: 1) отношение к природе; 2) отношение ко времени; 3) модальность человеческой активности; 4) модальность межчеловеческих отношений; 5) представление о внутренней природе человека.

Как видим, первый пункт предполагает обращение к природе. Проблема взаимосуществования природы и человека в ней - важнейший параметр при сопоставлении культур. Николай Александрович Бердяев писал, что русское мироощущение ближе к «духам природы», оно не сковано цивилизацией, более свободно в выборе средств и способов своего выражения. У французов, например, природное начало слабее, т.к. они имеют более древнюю культуру. Поэтому многочисленные исследования зоонимов, фитонимов в разных аспектах, которые, казалось бы, безнадежно устарели, позволяют посмотреть на них с иной стороны - с позиций процесса концептуализации культуры.

\section{Вывод}

Таким образом, наблюдения над языком позволяют понять глубину национального сознания, которое есть по своей сути языковое сознание.

В последние годы в лингвистической науке основополагающим стал постулат о том, что каждый естественный язык по-своему членит мир, то есть имеет свой специфичный способ его концептуализации. Постижение того, как именно человек воспринимает и концептуализирует действительность, какие факторы объективного и субъективного характера являются определяющими в формировании национальной картины мира, представляется чрезвычайно важным. Особую роль в когнитивных процессах играет метафора, в которой наиболее наглядно отражается национальная специфика мировосприятия. Поэтому обучать нужно не только владению самим языком, но и «образом мира» говорящих на нем.

Язык - единственное средство, способное помочь нам проникнуть в скрытую от нас сферу ментальности, ибо он определяет способ членения мира в той 
или иной культуре, он рассказывает о человеке и мире такие вещи, о которых сам человек и не догадывается.

\section{Библиография}

Бабенко, Л. Г. (2010). Концептосфера русского языка: ключевые концепты и их репрезентации (на материале лексики, фразеологии и паремиологии). Екатеринбург: Уральский государственный университет им. А. М. Горького.

Бодуэн де Куртэне, И. А. (1963). Избранные труды по общему языкознанию. Т. 2. Москва: Издательство Академии наук СССР.

Болдырев, Н. Н. (2009). Концептуальная основа языка. Москва: Флинта.

Гак, В. Г. (1988). Метафора: универсальное и специфическое. В: Гак, В. Г. (ред.). Языковое преобразование. Москва: Наука, с. 11-26.

Карасик, В. И., Стернин, И. А. (2005). Антология концептов. Волгоград: Парадигма.

Ковшова, М., Гудков, Д. (2017). Словарь лингвокультурологических терминов. Москва: Гнозис.

Ярцева, В. Н. (гл. ред.). (1990). Лингвистический энииклопедический словарь. Москва: Советская энциклопедия.

Лурье, С. В. (1997). Историческая этнологи. Москва: Академический проспект.

Мауро, Т. де. (2000). Введение в семантику. Москва: Дом интеллектуальной книги.

Пивовар, К. С. (2015). Беларуская ментальнасцьь у моунай прасторы мастаиякага тэксту. Віцебск: ВДУ імя П. М. Машэрава.

Телия, В. Н. (2005). О феномене воспроизводимости языковых выражений. В: Красных, В. В., Изотов, А. И. (ред.). Язык, сознание, коммуникация. Москва: МАКС Пресс. 